Thematic article

\title{
Religious Socialisation of Children and Youth in Eastern Orthodox Christian Church as Educational and Pastoral Challenge of Sharing of Cultural Practices
}

\author{
Liana Galabova ${ }^{1}$ \\ Recommended citation: \\ Galabova, L. (2020). Religious socialisation of children and youth in Eastern Orthodox Christian church as educational \\ and pastoral challenge of sharing of cultural practices. Central European Journal of Educational Research, 2(2), 1-16. \\ https://doi.org/ 10.37441/CEJER/2020/2/2/7909
}

\begin{abstract}
As a result of three decades of social-cultural transformation, Bulgarian literature and practice of religious education though still rare is increasing and improving. As the Church recovers, local parishes, monasteries, and convents become visibly re-socialised and motivated again to provide more adequate pastoral care for all ages. This study explores the importance of informal improvisation and innovation as an approach, in the best interest of children and youth, at a time when an effective, regulated mass public religious education system in Bulgaria is not likely to appear soon. At the same time, revitalised eparchial, parish, convent, and monastery centres start meeting actual needs of renewed church ethos, and begin to provide opportunities for religious socialisation of children and youth that is more functional. Based on direct and indirect experience, on observation, and on partial access to limited local empirical data (that is historically and/or anthropologically only partially explored and categorised), this paper contributes to the analysis of the following unresolved issue: how to direct research toward and keep account of well-known educational and pastoral practices, whether traditional or contemporary, that aid the effective and sustainable religious socialisation of children and youth.
\end{abstract}

Keywords: socialisation; education; children; youth; church; heritage;

\section{Introduction}

Resocialisation of confessional education in Bulgarian Eastern Orthodox Christian Church had become part of the democratisational cultural transformation process. Unlike religious education in schools and though church re-socialisation is basic to understanding doctrinal information, catechetics had not received sufficient public recognition, a sign of reviving live traditional heritage. Neither local contemporary history of parishes nor monastic educational activities became the object of considerable scholarly interest. Their virtue of humility, respect for collective and hierarchical principles of religious organisation, and the problematic subsidising of post-socialist activities for children and social care in general initially prevented clergy from engaging professionals in church spheres until they became conscious, active parish, monastery, or convent members, not only concerned, passive observers. Therefore it was not just pedagogical analysts who were not provided with enough consistent, reliable, public data. This information was necessary to produce valid quantitative or qualitative research results that could be systematised in real and adequate experience-based didactic and methodical outcomes, also compiling efficient guidelines or educational models, tools, or materials.

First-generation university, elementary or secondary school, and kindergarten prospective confessional teachers were trained as theologians and worked simultaneously in churches and monasteries, usually using the same pedagogical methods and materials. Old theological faculties, opened by the Sofia University in its memorial building in the early 1920s, was transformed into a clerical academy in early 1950s. It was then

${ }^{1}$ Independent scholar, Sofia, Bulgaria, lianagalabova@abv.bg 
reorganised in the early 1990s by its rector (a recent patriarch and metropolitan of Sofia), His Holiness Neophyte (Dimitrov), as its first contemporary dean. Newly opened faculties also needed some time to develop and enrich the existing theological curriculum, studies in various directions, and to refresh their staff and renovate structures. A number of inventions emerged as a result, results like teacher practice in kindergartens, schools, and universities, and not only in seminaries, theological departments and faculties, academies, parishes and monastic schools; like less discriminative recruitment of students at all academic and clerical levels, and like joint programs and projects that of pilgrimage and young parish (Figure $4 \mathrm{~A}$ ), which is the church equivalent of university kindergarten for students-parents.

However, local authorities and society did not yet trust, give voice to, or subsidise immediate mass religious instruction in Bulgaria for various post-atheist cultural reasons such as archaism, fundamentalism, discrimination, sectarianism, re-ideologisation, politisation, clericalism, etc. Initial problems and decisions for the reintroduction of religious instruction as an optional, regular or additional school subject in other cultural and confessional contexts of global Eastern Orthodox tradition inspired Bulgarian educational reforms on all levels, but demonstrated that legislation, subsidising, and organisation depend on creativity and values.

Revitalisation of church practices proceeded along three decades of gradual development and did not yet show any vivid signs of recovery, or respond to either the need of optional restoration of folk heritage or to any actual demands of renewed church ethos. At first Bulgarian clergy returned to pre-communist, modernist-traditionalist church disintegration, and suffered through extreme competition over sacred sites for a decade and a half, politicising faith. Two local theological approaches to confessional resocialisation that represent the memory and the idea of Bulgarian Eastern Orthodox Christianity developed as movements, being either more open to shared European and global cultural values, or more closed, clinging to reconstructed yet archaic, strictly traditional local organisation, and referencing identity and values that were reconsidered or revived.

Such a silent and gradual attempt at cultural creativity was understood and interpreted by local clergy, not as a peripheral geopolitical worldview, but as wise pastoral care made to work globally. Meanwhile, it was seen as more an adequate response to specific multi-ethnic situations of religious diversity, than to the broad spectrum of other Orthodox churches and communities. Due to the still very rare foreign training of clerical youth, church and academic exchange or movement of new theologians over the last decade of 20th century overwhelmed the historical, territorial and ethnic, opposition, thus having an impact on Eastern Orthodox Christian culture. Reviving of old tensions between religious centres from the past followed contemporary Russian, Greek, and Western cultural sympathies, orientations and affiliations by experience of sharing. The mobility of church communities, import of building practices, renovation and restoration of sacred sites and landscapes, opening of new theological units, and generational changes still lead to unexpected, dynamic cultural results that are not sufficiently systematised and explored, and deserve more interdisciplinary scholarly attention, especially in regard to youth and children.

\section{Research design and Method}

In continuation of my studies on theological university education, and on the transitional relation of children and youth to Eastern Orthodox Christianity through the educational system and religious communities, this research is based on qualitative methods and combines experimental and regular pedagogical practice, educational and confessional reflections, observations, reports, analyses, shared practices of recent, well-known teachers and scholars. Lack of proportionate, consistent and systematised data from the past, as well as from the present, on the background of undeveloped church and public religious education systems in Bulgaria better outlines particular practices and contributions, and their effect on the overall local situation and its dynamics, either during certain periods of time (from the aforementioned process), or throughout the entire new history of teaching religion in all its organised ways. In regard to pedagogical technology, direct observations of educational interaction with children and youth of various ages, from various backgrounds, in various local settings and with various levels of awareness of religious rights and belonging, bridged the analyses of what had been practised in cultural context in the past and of what was or could be applied to the near past or present (including that gained from international and inter-confessional or interreligious experience), with completely new elements (that may only need sociocultural "time" to be implemented), and with what has only become possible as an experiment oriented to the future (still in need of further elaboration). 


\section{Results}

Catechisation at any age against stereotypes of asocial clericality and popular religiousness: Educational challenges for socialisation of children and youth by adopting cultural experience

New forms of religious education were perceived as forming traditional identity, and gradually became more than particular heritage elements integrated in a general curriculum. Organised as living and real social practice, as found in occasional projects or in additional classes and kindergarten activities that are regular, optional, and limited opportunities, religious appearances attracted educators to contribute professionally to a field that deserved their personal interest and attitude (Vassileva 2010, 2009, 1999). Theologians needed pedagogical training and experience, just as kindergarten, school, college, and university teachers needed catechetical, church-based socialisation. By such joint expertise and vocation (Legkostup, 2019, 2017, 2015, 2012) church ethos started regaining its links to family, youth, children, subcultures and even to other public sectors thereby acquiring better socialisation overall. Only recently did particular cultural results become more objectively shared, documented, discussed, analysed, represented in the media, and taken into consideration for future systematisation and development (Spirova \& Karavalcheva, 2017; Spirova, Karavalcheva \& Antonova, 2017). Meanwhile numerous Bulgarian representatives participated in many local and international, intercultural, interconfessional, interreligious, interdisciplinary, and interinstitutional projects, teams, and regular forums that focused on religious education and socialisation, also organising exchanges and editions.

Fundamentalist and discriminative stereotypes related to gender, confessional, educational, social, and other basic human rights persistently reappear in Bulgarian social space in order to resonate and provoke society to provide adequate public responses. The most recent deterioration of church socialisation along epidemiological conditions of liturgical life, following the pandemic information campaign of the spring of 2020, is only reflecting contemporary religious lifestyles. Massive flows of information and technological advancement leading together to changes in civilization could have provided more rapid exchange of cultural innovations between local Eastern Orthodox Church structures, with regard to better transversal perspectives, than encapsulation. The reality of virtual liturgical life for contemporary clergy and youth who grew up within renewed global church ethos can help encompass situations and flocks. Bioethical challenge requires clerical adults, leaders and elders, as theologically wiser, more experienced in piety, more mature in Christian Orthodoxy, and more stable in their spiritual social position, to bless high and mass culture with their presence and expertise so as to leave a valuable legacy for future society.

Adopting many exemplary practical models from churches in other ethnic, national, and confessional traditions, whether or not they share the same communist heritage and legislative improvement, Bulgarian educators worked together with clergy to preemptively skirt eventual acute problems that were discussed and resolved in various local situations, and could also emerge in a country famous for its slow and most attentive church revitalisation and resocialisation processes. Nowadays the development of independent democratic reinstitutionalisation of confessional communities is affected by the material side of the management of the religious sector. Church centres and organisations were expropriated and only partially included in centralised and planned socialist economy, and, like many local charitable, educational, and academic units, became part of secularised and modernised social life.

Behind the economic crisis, low rate of gross domestic product and high level of poverty, combined with initial limitations to improve the Church situation, Bulgarian monastic culture is still underdeveloped compared to Eastern Orthodox Christian sister-churches. This is not only due to former security control and state intervention in clerical human resource sector. Putting aside development differences and ethnic belonging to only one of the competing Balkan and Slavic East Orthodox Christian groups, migration for Bulgarian clerical youth to the places where ascetic church ethos and life were unaffected or more rapidly recovering became an option. Hence only first-generation monks and high clergy could, after social change took place, provide living models and innovative experience inside church ethos. Therefore at the beginning of transformation, the lack of local youth confessional policy seemed casual against the backdrop of cultural policy stagnation in general.

\section{How educators cooperate with clergy to combine pedagogical and pastoral approaches}

Although there were already several children's and youth's camps and educational activities in parishes, monasteries and convents, like Hadzhidimovo, Etropole, and Samokov, their actual impact was limited to church families and local people letting their siblings attend religion classes or kindergarten activities. Whether subsidised by the Church as motivation and reward for joining the still problematic and rare religion classes and 
parish Sunday schools, or organised by educators as an additional cultural activity, the pilgrimage of children and youth, as well their recreation, generally stimulates the rehabilitation of sacred places in a different way than other forms of tourism. As in recent examples of renovated monasteries in Gigintsy, German, and Kremikovtsy (Stoyanova \& Malamova 2019), which regularly hold and receive child and youth camps and pilgrimages, various approaches in organisation of ascetic, festive, and social revitalisation, resulted also in effectively meeting the educational requirements of an ergonomic and safe environment, as well as providing accessibility for people with special needs. Sustaining the prayer life of monastic communities and pilgrims results in more direct involvement of youth and children in spiritual life, less fear of devotion to church, and the fluid, proactive transfer of tradition to the next generation.

Since many sacred sites keep or include playgrounds in their yards, during socialist times and in new international models too, it was only recently that more parishes began to consider developing special liturgical and catechetical spaces in naves (Figure 1. a.) that would be optimal for children. A sign of greater concern over early church socialisation is the creative pastoral organisation of church family, youth, and child subcultures. Instead of just leaving the young believers (who are less than a meter tall, and not yet ten-years old) to get lost in the crowd, to freely play around, or to be put in separate rooms during services, without measuring the risk of damages and injuries professionally, methods of organisation were developed. Some of these methods or solutions recorded by local history are the following: moving the parish and childcare centres from the Sofia seminary by new and exemplary monastic principle staff, closing the park to the public, and keeping only sportive, recreational spaces.

Male clerical high school had been evacuated several times from its building and temple in the city centre, when Sofia was bombed during WW II, when the seminary was given to an agrarian higher school, and later when the place was transformed into a communist pioneer palace for children and youth - all in all, it was vacated during the first and second halves of the 20th century. In comparison, the Annunciation Convent in Gabrovo that had been organised in the past with the purpose of being a female school for teachers and nuns, at the end of the 1950s lost its social support and was demolished. Although in Bulgaria there are excellent minority religious schools, for boys and for girls alike, seminaries as units of church high education still do not consider the equity of girls' training. Thus, parents would rather send their children to neighboring boarding schools, remaining more interested in home education than in the denomination of the majority.

Old traditions of joint church and school institutionalisation were modernised by the addition of reading houses (chitalishta) and were later seen as lacking the church education and social care system (from elementary to higher school) found in the Russian example devised by Russian patriarch, His Holiness Cyril (Gundyaev). Its development continued with the contemporary acceptance of women in theological seminaries following high schools. Empowering church children, youth, young clergy, and laity with social skills and attitudes to build strong and healthy relationships supports the embodiment of church ethos into exemplary Eastern Orthodox Christian personality and group competence, enabling them even to sustain huge families, bring up many consequent children and raise successful members of parish, of monastic communities, and of society in general. Therefore any stereotypical framework of church-related education or social care is to develop, from cause and campaign to regular service, and from simple publically approved ideas to clearly motivated contemporary practice that relies on effective methods to reduce potential group and individual risks. These are in accordance with general aims and goals based on values shared among maximum stakeholders.

Nevertheless, the isolated attempts to promote more rapid reintroduction of religious education, either confessional, or comparative, and the occasional specialized project in the past deserve further thorough analysis. Even the various unrelated instances when children and youth get involved in church activities (pilgrimages, festivities, charity activities, creativity, media, and everyday life) and the problematic experiences that form them demand scrutiny. For example, a convent famous in the past for development of highly active church movements, nowadays relies, in a big way, on nostalgia to regain its ascetic life - from private to public, from secularised to clerical, and from civic to religious socialisation. A new community started attending the convent, and as soon as large amounts wall encompassed church land preventing expansion, it lost its role as an urban religious centre. Thus, its doors closed, following a strict liturgical schedule in order to limit communist use of the space as a as playground near the monastic graveyard. In this south-eastern region of the city people protested against the new church project in the park, and in response the new parish was supplied with a huge abandoned area, promising to build also a cultural centre, and several chapels in remote locales of the district, a strategy which is gradually becoming reality. 


\section{Shifting catechetical objectives from etiquette to ethos, values, mentality, and worldview: Pastoral challenges when education resulted in opportunities to share cultural experience}

Early post-communist educational and Church initiatives, organised in support of raising the religion awareness of children and youth, appeared occasionally in the late 1980s, when socialist interest in local heritage was part of cultural equity policy. Reviving the eclectic, festive, and religious elements of Bulgarian national identity, and, based on the vast legacy of ethnological research (Simeonova, 2000) left by previous cultural reconstructions and artistic stylisations, people started travelling abroad more regularly to visit world heritage and sacred sites, while children and youth also began to notice the confessional aspects in everyday life and in cultural expression. Civic effects of mobility also remained less visible prior to the start of eurointegrational and other geopolitical processes, in 2007 when Bulgaria and Romania joined the European Union, and while local churches were resocialised locally in quite different ways.

Local university and publishing reforms in post-socialist countries went on in various ways, following improvised youth and cultural policies and legislation renewal in religion and social care. One of the first popular, international, religious editions of that time was the tiny church colouring booklet Orthodox services, sacraments, and practices illustrated by Irke Petterberg-Laurila in Finland in 1988. Translated for most local Eastern Orthodox Christian churches, this brochure-like, improvised, clerical travel book oriented people in sacred spaces, and came to Bulgaria in 1992 as a freely distributed edition of Saint Patriarch Euthimios, the Eastern Orthodox Christian youth movement supported by the Balkan Orthodox Youth Organisation [BOYA]). Created to thoroughly reflect the course of parish life at specific church locations, this simple edition also became a reliable starting manual on liturgy and a dictionary for all the school years from the 1990s to today. This came a time when most local metropolitan websites, as well as dozens of informal clerical journalists, provided constant, continuous detailed document sources on liturgical life, textual, photographic, along with video materials covering all local worship services. At first, television transmissions, programs and reports on Eastern Orthodox Christian life (by personages like Maria Popova, Marin Gradinarov, and Goran Blagoev, and more, ) were very instructive and complex, instead of festive and pilgrimage-oriented, also entailing rare elements for children.

Available Bulgarian catechetical literature was limited to several communist church editions like, Our faith from the early 50s. Its authors were the Most Reverent Fathers, Archimandrite Nicholas Makariopolsky (Kozhuharov) (artist, calligrapher, church musician, and later bishop and rector of Theological academy) and Archimandrite Seraphim (Alexiev) (one of the prominent local church poets, a traditional preacher, educator, theological scholar and assistant professor), who continued the edition in the book, Our love, (a popular interpretation of the Holy 10 Commandments) and in, Our Hope (a book on the Nine beatitudes). Only in 1993 had the beloved, worldly book of Russian émigré catechism, Divine Law for home and school - by artist and icon-painter, organiser of church child and youth camps, prominent parochial priest, and later Most Reverent Protopresbyter (Archpriest) Seraphim Slobodskoy, appeared in Bulgarian churches as a donation from the Job of Pochaev Holy Trinity Monastery Press in Jordanville, New York, and had been unofficially translated into Samizdat Bulgarian by High Reverend Protoyerey Borislav Manchev in 2001 in the Assenovgrad edition. Edited and illustrated by only one parochial priest family, an exemplary contribution to missionary work done by the Russian church diaspora, this book came just in time from democratic space over the ocean to support first-generation teachers whose work could still benefit from Russian sources.

English translations and original works for émigré communities around the world, as well as local Russian, Greek, Romanian, Serbian, Macedonian, and Bulgarian Eastern Orthodox editions, later translated into English for the purpose of reintegratino parallel church structures in the diocese, became the prestigious model for future educational and editorial confessional work, while a bookstore chain started importing rich Russian literature, including limited copies of Eastern Orthodox Christian books. Limitations in the use of Russian sources in Bulgaria came along with generational change, temporary cultural and clerical local reorientation, causing a delay in the translation of valuable reprints and excellent new works in the field of confessional religious education, into Bulgarian. While the World Wide Web was still constituting a new information society, Bulgarian church teachers were happy to use it experimentally in their work, creating precious youth books with sincere pastoral messages, for example, that of High Reverend Archpriest Artemiy Vladimirov on child confession, and Life manual for home and school reading (Uchebnik Zhizni). Through the well preserved Russian editorial system, Bulgarian educators could actually follow the development of Russian regional teaching experience into federal practice, as in the cases of complete textbook sets on Basics of Orthodox culture by Alla Borodina, Olga and Roman Yanushkyavich, and other authors. There were also 
numerous supplementary materials like illustrated bibles, abecedaries, prayer, musical and theatre books, chrestomathies, plays and toys, etc. The Russian church editorial mission also included artistic translations and illustrations of Bulgarian and other children's and youth books on local saints and history. As an example of this, one might mention one of many popular works by Reverend Mother Abbess Valentina (Drumeva) who organised confessional education of children in the Kalofer convent.

Mass local donations of interconfessional-edition illustrated Bibles and Christian ethics textbooks were for a long time the only religious books for children and youth. The only exceptions were national and multicultural heritage editions of history and feasts that balanced out the influence of incomparable experience and abundance of educational materials of heterodox Christian denominations. In previous years, while social media weakened the importance of church pedagogical communication through reading books and formal teaching structures, Slavonic services and theological references are already gradually being translated into contemporary Bulgarian, and liturgical life has also been adopting digitalisation and virtualisation practices. Nevertheless, Metropoly of Lovech developed a church editorial program for children and youth, and, together with original luxury books on the lives of local saints and elders, finally translated the best Eastern Orthodox creative, visual, catechetical work, Gospel retold for children (Evangelie v pereskaze dlya detey: vozrastaem v dobre i svyatosi) by Natalya Davydova, Tatyana Kiselyova, Viktor Korniyshin, and the Moscow Holy Trinity and saint Serge monastic press.

Bulgarian children, teachers, and parents were fascinated not only by foreign media reports from parish and monastery recreational, musical, scenic, sportive, and folk dance initiatives and regular activities, but also Bulgarian believers for a long time were impressed by children's editions in Greek (translated by Potamitis press), Romanian (of Saint Mena press), Serbian (Beseda), and many more, using them for home, school, or church education - together with several translations from Skrino monastery and other publishing houses. Yet, in the early 90s, for clergy involved in kindergarten activity, there appeared small booklets with wooden building blocks featuring icons of saints and feast scenes; calendars with icons that functioned well as teaching albums; and other children's materials which were available at Bible societies, Protestant or Catholic bookshops, and publishing houses. All the while, church history could be taught from general educational literature, local as well as international (since general educational materials were on the rise), though there were few children's books (including periodicals, religious art, travel, and musical editions) from the Synodal and Tavor press, Zograph and Scrino monasteries, Knyazhevo convent and Seven saints foundation, from local parishes, monasteries, and pilgrimage centres. Fascinated by the cultural context found in more church-oriented children books such as Tomorrow is Sunday (and other works by Galatia GrGrigoriadou-Sourel), by original illustrations in ethnic iconic style, and by the educational blogs of priests and bishops (patriarchs, metropolitans, and archbishops), priestesses (wives of priests), monks and abbots, nuns and abbesses, mothers, teachers, and by ordinary believers, local people realised that changing their environment via more creativity could lead to advancement in youth policy. Only then could the Russian parish in Sofia organise the recent Bulgarian translated edition of Sacred history from Adam to me by Reverend Deacon Ilya Kokin, based on the artistic work of Evgenii Podkolzin from his world famous émigré confessional textbook - the only textbook from a perfect, innovative, pedagogical system based on much church service and teaching experience, and a cultural scholarly approach.

\section{Why child and youth church subcultures needed previous experience and reflexivity}

In the 2013-2014 school year alone, a team of two theologians-medievalists, a church journalist, Eastern Orthodox Christian SYNDEMOS and BOYA activists, an experienced Pokrov foundation Parish centre catechist, and social work project manager and educator, step by step started editing and approbating the prestigious textbook system of the Dveri foundation for non-intrusive work on traditional confession in public schools by general education teachers (Spirova, 2015). Exploring heritage content on the doctoral scholar and teaching level, the Dveri team, with the approval of authorities, organised many public trainings with and showings of their booklets in order to present to the people the new cultural product that had been subsidised on project principles, distributed to teachers and pupils, as well as to clergy and parishioners as free educational material. They faced its real and potential target groups, and the spring of 2020 was the first to provide open-access online resources for at-home and distance learning during the pandemic situation, implying mobility limitation and closure of educational and religious institutions. Accomplishing simultaneously the tasks of providing both long-awaited multifunctional and age-specific original Bulgarian teaching material on religion and church, the Dveri education manual system also compensated for the deficit of theologians and 
other humanitarian specialists who could only work as confessional teachers part-time, and it even helped authorities avoid the cost and regulation of pedagogical training, the hiring of separate educators, and the problem of organising additional classes and activities that may disturb the rhythm of kindergarten, school, and university subcultures.

Focused on the non-violent effect of religion in child development, rather simple, ergonomic, and stylish, than ornate and over-informational, Dveri's informational and integrational confessional education sent positive messages, blessed and inspired, this being paralleled by the exemplary social work of one of the first contemporary, working parishes in Sofia. First-generation post-communist families were consolidated both culturally and pastorally. At the Protection of Theotokos (Pokrov Bogorodichen) church and non-governmental organisations, in every way possible, worked hard to professionally cover all possible church activities in order to build a culture and modern representation of faith. In about a decade of seeking to adopt and exchange information and experience, the Dveri foundation team started inventing innovative educational approaches for their child and doctoral research.

In a sociocultural campaign, the hosting of occasional, and regular public institutional religious activities, “Team" Dveri also provided opportunities of pedagogical improvisation and informal learning, redirecting public demands for revival of church tradition back to more natural, relevant sites like the parish, convent, monastery, and other communities for the revitalisation of Eastern Orthodox Christian heritage. Therefore such specific editorial initiatives from the last decade decreased the tensions between clerical and civic authorities, sharing the responsibilities to provide religious education rights, not yet clearly articulated in strategic documents and guidelines (Spirova \& Karavalcheva, 2017; Spirova, Karavalcheva \& Antonova, 2017). For these rights had yet to be made visible in local policy, as for example by renewable concepts of youth and social work in the Russian Orthodox church (Kokudev, 2019; Alexandrov, 2014, Kirov \& Nushev 2007). Hence the communication between educational and church domains became more effective and democratic, and theologians could concentrate on the cultural contribution of church socialisation to global identity.

Compared to more developed educational cooperation between Romanian priests and confessional teachers (Gordon, 2015), Bulgarian practice is still experimental, although, from the beginning, religious education activities involved also bishops, priests, priestesses, monks, nuns, church singers, icon-painters, and other church officers, members of parishes and church families. Most Reverent Father Zachary (Dechev) became one of the first parish priests to implement more well-known and feasible forms of Eastern Orthodox Christian church activities, edited textbooks, curricula, and methodical guidelines in his pastoral care for children and youth - even teaching, working in the tourist and heritage sector, and completing a pedagogical dissertation. While his Eminence, a Hillarion Dorostolski (Tsonev) local, High Reverend Archimandrite Seraphim, Reverend Abbess Valentina (Drumeva) Ivan Nikolov, and other church poets and writers together provided inspiration through some narratives and educational works, Dimiter Kirov, Dechko Svilenov, George Bakalov, Ivan Zhelev, Emilia Vassileva, and other authors, including some of the best practicing teachers, edited the first new textbooks (Blagonravie) and art photographer Mikhail Enev and artist Cyril Giylemetov became the first illustrators and book designers. At the same time other theologians organised parish and monastery centres working with people from health, social work, and confessional fields, who were interested in church education, arts, and services pertaining to children and youth.

At the beginning of the 21 st century, European integration, the end of the local church split, reduction of political polarisation and global processes focused church attention on persistent culture problem of training local teachers in comparative religions, and of editino children's textbooks, combining Abrahamic monotheist religions with more philosophical Eastern thought, new religious movements, and local cultural heritage, in a process of civic education in human rights with regard to human values. Educational practice resolved methodological work deficits in multicultural kindergarten groups, school classrooms, college halls, and university auditoriums. And though church education did not have the same problems, the concept of home-schooling for religious purposes did not gain popularity in private theological universities, schools and kindergartens. What's more, video lessons and live streaming did not abruptly appear in response to media democratisation, even in light of the recent threat of extreme social change in traditional attitudes toward church culture.

Theologians, still working on high quality representative textbooks like the anticipated and almost finished Sunflower system for children, expressed concerns over risks of improvisation, preferring educational materials that was more carefully edited (though its completion was more painstaking), informally illustrated and that had kid's art too. Richly developed materials are founded upon on lots of teaching experience, approval by high-ranking teachers, and references from experienced pedagogues and interdisciplinary teams. Oftentimes, 
they are supplied with enormous methodological analyses and guidelines, openly distributed on the market together with children's periodicals, and donated by churches to teachers, as well as to children and youth, regardless of the type of education institution. Teachers' background in traditional folk music allowed them to create highly artistic products, and cooperate with toy designers, resulting in textbooks' story-tellers being represented by dolls. High school textbooks are still expecting to be developed, although youth religious education, especially in parishes in Bulgaria, is less popular. Although, comparative and practical confessional views ought to be more comprehensive for young people.

\section{Why problematic aspects of clerical communication with children and youth and their inclusion in religious community should not affect their mission to benefit from confessional socialisation, and improve their future churches and societies}

Economic sustainability as a traditional precondition of any local church mission (Kozhuharov, 2010, p. 84 ) is not only a matter of canonical or occasional participation of children, from birth, in church practices (Figures 1. b. \& 2 a). Confessional youth policy is not merely the consequence of political balance of religious and social care legislation, although it is an issue brought up at local church councils, and at events like protests. An example of such is the spectacular procession by church nationalists in September 2010 (Alexandrov, 2015, pp. 92-93), when clergy and believers from all over the country gathered at a youth concert in the centre of the capital (Figure 2. b.). Authorities ought not take confessional school subjects as literal church instruction, whilst waiting for constitutional changes, or modifications in laws on religion, education, culture, social services, etc.

Provided that, for identity reasons, the state still trains Eastern Orthodox Christian theologians to be teachers in the educational system, legally defined by republican legislation as secular (Alexandrov, 2015, p. 94), the creation of a belief-neutral and human-rights-aware public environment should be a responsibility shared equally between church and state (Alexandrov, 2015, p. 95). The wish to diplomatically avoid (and not deal with) the dynamics brought by the regular presence of children and youth in parishes and monasteries is not just postponing pastoral duties, it is disregard for reality and neglect of future. Not addressing the mess of curriculum and schedule, didactic problems, and the costs of introducing religious elements into formal education (Figure 3A) is to deprive subcultures of children and youth of more structured and regulated ways to experience non-discrimination, and local traditional culture. Hence church education might risk training discriminatively, because of the very fact that for all children and young people it is scarce, guaranteeing that communities of kids would be split.

Homiletics should be applicable to everyone in the church community, reaching them as one unified flock, without neglecting or underestimating the vastness of variety in teaching (Alexandrov, 2018, p. 273). With that said, one of the serious difficulties of preaching is always categorisation of audience, not only based on age and social differences, but also based on personal or group expectations (Alexandrov, 2018, p. 252). Defined more than 80 years ago by the theological, social insight of revolutionary modernist thinker and activist martyr and saint Maria Skobtsova (Skobtsova, 1937/2006), it is the hard task of tuning catechetic or pastoral communication, tailoring the content of messages to contemporary parishioners, in order to relate to believers' internal differences. Thorough analyses are based on her émigré experience in confessional development, through the stages of synodal, canonical, aesthetical, and ascetic piety until the development of the current state of Christian evangelical faith, expressed in monastic devotion and existential self-sacrificial societal service and martyrdom. According to her impressions, Eastern Orthodox Christianity's personality remains incomplete and deviant, asocial and dangerous, especially in cases of unwillingness to repent and progress. Refusing to publish her contemplations based on first-hand accounts due to their possible judgmental or offensive nature, Mother Maria became helpful not only to later analysts of that period, but also to specialists working on criteria to better define the non-inhomogeneous target group of their pastoral work (Alexandrov, 2018, p. 268-270). Children and youth are living examples of the value of exceptional presence in the flock, with their need for exemplary, beautiful, attractive, ascetical, and yet simple messages in language they can understand. This is particularly true among predominantly unknown recipients of church homilies (Alexandrov, 2018, p. 271) like global and invisible audiences reached by contemporary media, either invocationally or mystagogically (Alexandrov, 2018, p. 195). Children and youth in church are also a motivation to make preaching differ from everyday communication, education, and recreation. It is a drive to visualise and perform, rather than speak, to be able to represent serious matters and link them with quite different mood and attitudes.

Religious education rediscovered its church context as soon as liturgical life became a regular, common, and well-represented public activity, publicized in traditional and new media, stressing local cultural identity, 
and supported not only because of the clerical labour market. Against the problematic background of three decades of discussions about the nature of religious schooling, having been explored by numerous specialists past and present, locally and around the world (Mitropoulou, 2015; Yanev, 2012; Bogomilova, 2010; Kalkandzhieva, 2008; Denev \& Groß, 2004; Groß, König \& Andonov, 2003), parish and monastic youth activities gradually gained status as culturally reliable and free opportunities of parent-controlled church socialisation, common in many other traditions, including Bulgarian (Figures 3 \& 4). Dependent on clerical blessing, on general consensus, and assistance from the whole flock, pastoral care for children and youth (Figure 5) includes age-specific education, presence thereof even in mixed groups, and by improvisation methods.

More or less, a formal church education follows pedagogically appropriate calendar principles of structuring theological, doctrinal knowledge for children, and their religious socialisation, by educational interaction, that may include any appropriate active form of worship and lifestyle. Church practice assures complete comprehension of daily, weekly, and yearly liturgical cycles, and live events, with their celebrations and rich poetical, rhetorical, musical, visual, performative, and other heritage and creative opportunities, assure a chance to put that liturgical learning to use. The activities organised for children or young people by parish, convent, monastery, or any other Eastern Orthodox Christian unit are not limited by certification and regulation by state authorities regarding religious instruction. Sometimes they pretend to represent and assist churches, other times discriminating against teachers, parents, and children, if there is no agreement between the municipality and eparchy on the shared subsidizing of regular classes and full-time teachers.

In the exemplary case of eparchy of Plovdiv, His Eminence Metropolitan Nicholas (Sevastiyanov) blessed and subsidised optional confessional education in public schools, as well as free parish courses of church arts, and founded a clerical academy to train priests and teachers in the region. Plovdiv theologians may be qualified in pedagogical programs, but they are not obliged to choose the more stable social position of assistant educator, kindergarten or primary teacher (as in Sofia), in order to teach only several hours weekly, and to avoid meeting actual religious educational demands. According to my observations through the period studied, best practices generally reach about 50-70\% attendance opted by informed Christian families, and about 90\% of Muslim parents. The participation of children and youth in well-organised activities of religious communities, general or specific, is approximately the same or higher, and, hence, preventing authorities from tampering with already legalised confessional education.

\section{Discussion: Recent perspectives of sustainability and progress in Eastern Orthodox Christian church socialisation of children and youth as a more common global cultural practice in Bulgaria}

Much time has been taken to contemplate the great responsibility of creating open catechetical resources for children and youth. History, tradition, and heritage are the roots from which come a limited eclectic compilation of more or less adequate texts, images, melodies, scenarios, and methods, which were implemented in order to perform occasional church-educational tasks. The educational nature of real liturgical life in the Eastern Orthodox Christian Church is informally accomplishing practical, sacred socialisation of all people better than any media: paper or digitalised textbook, audio-visual and performative materials, websites or mobile applications, and even communicational technologies of the future. Religious importance of the human factor, rather than institutional power (Malamyn-Syriysky, 2020) exceeds the level of introduction, translation, representation, decoration, providing atmosphere and resources, communicating values and attitudes, activation of pastoral and social care, together with church accommodation and inclusion, or even regulation and legitimacy, in the management of child- and youth-friendly church space and community.

Theological education as a matter of mature choice, and already considered youth space, is still the best institutionalised representation of church societal practice. Therefore faculties recently deserved state protected status, although their problematic academic accreditation is related to the limited number of student applying and the tangible absence of relevant job opportunities for prospective graduates. Catechetic and interdisciplinary roles of theological units gained cultural importance before democratisation processes, specifically in the fields of heritage studies and arts. Opportunities for church projects through non-governmental organisations became more available recently after decades of centralisation, due to the exemplary experience of the Pokrov foundation and Omophor publishing house still a leader in creativity, quality and scale. Choice between cultural and societal service becomes necessary because of the difficulty of parish children and youth to communicate with social care target groups, usually isolated and discriminated 
representatives of young local population enclosed in state institutions. At the same time, in the everyday life of the Church, devoted care, assertive communication, and sacred celebration can be found - creative and proactive - even in its most popular dimensions like management, tourism, recreation, cooking, cleaning, and gardening. Especially for youth and children who value simplicity, sincerity and authenticity, confessional activities are supposed to be more than attempts to draw public approval in order to gain a voice, space, and power. The smaller and less mature the child, the greater the concern about what parish is and looks like, or what it actually is or can ever become.

\section{Conclusions}

This observational and analytical opportunity to objectively reflect on religious socialisation of children and youth in Eastern Orthodox Christian Church is not only a pursuit of publically approvable, adequate responses to the particular educational and pastoral challenges of - accommodation, variety, or globally acknowledged cultural practices. Due to the recent rapid civilisational changes, achievement of a clear systematic view on these processes seems to be representative of a past situation that would probably not reappear in the future. Thus, that achieved experience is more a heritage value than a specific methodology to be relied on further. Nevertheless, three decades of shared experience regarding post-socialist parish education, related to more or less developed and resocialised church traditions has provided solid ground for what would be future Bulgarian Eastern Orthodox Christian church identity on societal, group, and individual levels.

With references to the shared results of practices done by other churches and countries, this is not just a simple collage with a lot of blank areas deserving more scrutiny, but rather a full picture of Bulgarian confessional church training of children and youth - past and present -, by including them in parish community. Socialisation of local children is not just a considerable part of transmitting living heritage that is able to create religious spaces, even when it is organised better by educational and other institutions. The research outcome suggests further study be given.

Although local tradition of catechetics is still developing its potential and scale, and compensates for the deficiencies from the past, it is facing cultural obligation to keep revitalising specific religious heritages based on civic and informational principles to make them applicable to general and global human values. The emerging awareness of choice as a human right on the individual level, and the dynamics of being all-inclusive in a particular church atmosphere are the drives to develop experimental and improvisational forms to solve the everyday service, liturgical worship, and festive life problems in a sacred space. Contemporary church communities and places of worship are created and inhabited by people that do not necessarily represent similar lifestyles yet. Thus can only aim at what they think would become an exemplary parish or monastic community focusing special attention on actual needs and demands of all church members together.

Acknowledgments: This research is supported by academic advice and historical reflection of associate professor Andrian Alexandrov, teaching Catechetics and Homiletics at Theological faculty of Sofia University and by the PhD student supervised by him - Velina Toneva who assisted me in a variety of observations during her work as a parish, kindergarten, and school teacher. She did this while working on a thesis on innovative pedagogical technologies in contemporary resocialisation of church education of children and youth - teaching in the Nativity of Christ church parish centre in Mladost's 3rd district of Sofia, Bulgaria, and actively involved in training, educational and cultural activities of the Metropoly of Sofia.

Conflicts of Interest: The author declares no conflict of interest.

\section{References}

Alexandrov, A.V. (2018). Propoved, propovednik, slushateli [Homily, preacher, audience]. Regional development foundation.

Alexandrov, A.V. (2015). Religious education in Bulgaria: Past and present. In R. Aikonen, \& A.V. Alexandrov (Eds.), The Orthodox Christian Religious Education Association [OCREA]: Methods of teaching in religious education: Learning by heart, or by experience? (pp. 86-96). Regional development foundation.

Alexandrov, A.V. (2014). (Eds.). Sotsialno-milosardna deynost na Tsarkvata: Strategicheski nasoki [Social-charitable activity of Church: Strategic guidelines]. Regional development foundation.

Bogomilova, N. (2010). Prepodavaneto po religiya v grazhdanskite uchilishta: Aktsenti v savremenniya evropeyski debat [Teaching religion in civic schools: Accents in contemporary European debate]. Electronic journal LiterNet, 10, 131. 
Damyanova, E.A. (2008). Muzeyat kato sreda za pravoslavno obrazovanie [Museum as an environment of Eastern Orthodoc Christian Education]. Sveti Nikolaevski pravoslavni obrazovatelni cheteniya [Saint Nicholas Eastern Orthodox Christian educational readings], 6, 247-252.

Denev. I., \& Groß, E. (Eds.). (2004). International symposium on Religious education in Bulgaria: Religious education within the Context of European Home. Faculty of Theology of Sofia University.

Gordon, V. (2015). Learning by sharing experience: Cooperation by the teacher of religion and the priest for the successful education of children in the Romanian Orthodox Church. In R. Aikonen, \& A.V. Alexandrov (Eds.), The Orthodox Christian Religious Education Association [OCREA]: Methods of teaching in religious education: Learning by heart, or by experience? (pp. 65-74). Regional development foundation.

Groß, E., König, K. \& Andonov, B.B. (2003). Religiozna pedagogika: Religioznoto obuchenie v enoriyata i uchilishteto [Religious Pedagogy: Religious instruction in parish and school], Synodal Press.

Kalkandzhieva, D.V. (2008). Religious education in Bulgarian public schools. In G. Pusztai (Eds.), Religion and Education: Vol. 3. Education and Church in Central and Eastern Europe at First Glance (pp. 167-177). CHERD.

Kirov, D.S., \& Nushev, K.K. (2007). Sotsialnata misiya na Balgarskata pravoslavna tsarkva [Social mission of Bulgarian Orthodox church]. University press.

Kokudev, S.R. (2019). Eklesiologichnite predpostavki na "Osnovi na sociyalnata kontseptsiya na Ruskata pravoslavna tsarkva": Nyakolko vaprosa za razmisal [Ecclesiological prerequisites of "Fundaments of social concept of Russian Orthodox church: Several questions for contemplation]. Hristiyanstvo i kultura, 10(147), 7-81.

Kokudev, S.R. (2013). Enoriyskite obshtnosti i virtualnoto hristiyanstvo: Opit za reflexiya varhu posttotalitarnata tsarkovna identichnost [Parish communities and virtual Christianity: An attempt at reflection on post-totalitarian church identity], Hristiyanstvo i kultura, 4 (81), 101-152.

Kozhuharov, V.Ts. (2010). Hristiyanska misiya v usloviyata na pomestna rsarkva: Misiyata na balgarskata pravoslavna tsarkva [Christian mission in the conditions of local church: Mission of Bulgarian Orthodox church]. Vesta.

Kozhuharov, V.Ts. (2001). Pravoslavnoto obrazovanie v didakticheska svetlina: Teoriya i praktika na savremennoto uchilishtno pravoslavno obrazovanie [Orthodox education in didactic light: Theory and practice of contemporary Orthodox education at school], Orthodox Theological Faculty of Veliko Tarnovo University.

Legkostup, M. (2019). Metodicheski aspekti na obuchenieto po religiya [Methodical aspects of religious education], Faber. Legkostup, M. (2017). Inovativen model za podkrepa na obuchenieto po religiya na teritoriyata na Obshtina Kiuystendil [Innovative model for support of religious instruction on the territory of Kiystendil municipality]. Obrazovanie $i$ tehnologii, 8, 75-80.

Legkostup, M. (2015). Case studies in religious education as a method of experiential learning. In R. Aikonen, \& A.V. Alexandrov, (Eds.), The Orthodox Christian Religious Education Association [OCREA]: Methods of teaching in religious education: Learning by heart, or by experience? (pp. 42-48). Regional development foundation.

Legkostup, M. (2012). Obuchenieto po religiya: dialog i inklusiya [Religious instruction: Dialogue, and inclusion], Faber.

Malamyn-Syriysky, M. (2020). Hristiyanstvoto se nosi ot konkretnite lichnosti, a ne ot darzhavata [Christianity is carried by particular persons, and not by the state]. Hristiyansvo i kultura, 1(148), 5-13.

Mitropoulou, V. (2015). Integration of learning objects in educational scenarios for teaching religious education. In R. Aikonen, \& A.V. Alexandrov (Eds.), The Orthodox Christian Religious Education Association [OCREA]: Methods of teaching in religious education: Learning by heart, or by experience? (pp. 113-121). Regional development foundation.

Nazarska, Zh.D., Garvanova, M.Z. \& Shapkalova S.A. (2016). Opazvane na nematerialnoto kulturno nasledstvo: Religiozni tsennosti v savremenna Balgariya [Preservation of the intangible cultural heritage: Religious values in contemporary Bulgaria.]. Za bukvite - O pismeneh UniBIT press.

Neminska, R. (2016). Religioznata obrazovanost v inovativnoto balgarsko uchilishte: Ili za potrebnostta ot vrashtane kam temata [Religious level of education in innovative Bulgarian school: Or about the necessity of return on the topic]. In I.N. Nikolova, M. Zagarova, \& E. Kovacheva (Eds.), Misal, slovo, text: Vol. 2. Traditsia VS theologiya: Sinergiya $i$ praktika [Tradition vs. theology: Synergy and practice] (pp. 109-113). University press.

Nikolova, I.N. (2016). Interaktivnoto obuchenie po religiya: vazmozhnosti i granici [Interactive instruction in religion: opportunities and frontiers]. In I.N. Nikolova, M. Zagarova, \& E. Kovacheva (Eds.), Misal, slovo, text: Vol. 2. Traditsia VS theologiya: Sinergiya i praktika [Tradition vs. theology: Synergy and practice] (pp. 114-133). University press.

Simeonova, G.G. (2000). Traditsionnite praznitsi v sastoyanie na promyana [Traditional feasts in condition of change]. Sofia: BAS.

Skobtsova, M. (2006). Tipove religiozen zhivot [Types of religious life] (I. Alexandrova Trans.). Omophor (Original archival work written in 1937 in Paris). 
Spirova, P. (2015). One possible approach to religious education in Bulgaria: Concept, implementation and results. In R. Aikonen, \& A. Alexandrov (Eds.), The Orthodox Christian Religious Education Association [OCREA]: Methods of teaching in religious education: Learning by heart, or by experience? (pp. 97-105). Regional development foundation.

Spirova, P., Karavalcheva, Z., \& Antonova, Ts. (2017). Strategicheski nasoki za razvitieto na religioznoto obrazovanie v Balgariya [Strategic guidelines for development of religious education in Bulgaria]. Center for Educational Initiatives Dveri.

Spirova, P., \& Karavaltcheva, Z. (2017). Modeli na satrudnichestvo mezhdu Tsarkvata, obshtinskata vlast i darzhavata za provezhdane na religiozno obrazovanie v Balgariya (1997-2017) [Models of cooperation between Church, public authorities, and state for instrumentation of religious education in Bulgaria (1997-2017)]. Centre for Educational Initiatives Dveri.

Stoyanova, N., \& Malamova Ts. (2019). Pravoslavnite lageri v Kremikovskiya manastir Sveti velikomachenik Georgi Pobedonosets [Eastern Orthodox Christian camps in the monastery of Saint great martyr George the Triumphant in Kremikovtsy]. In Zh.D Nazarska, \& S.A. Shapkalova (Eds.), Harmoniya v razlichiyata [Harmony in varieties] (pp. 256-259). Za bukvite - O pismeneh UniBIT Press.

Vassileva, E.L. (2010). Religious education as way to spirituality. In D. Opriş \& I. Scheau (Eds.), Summa Theologia: Vol. 1. Educatia din perspectiva valorilor [Education in value perspective] (pp. 20-29). Editura Aeternitas.

Vassileva, E.L. (2009). Duhovno-nravstvennoto izrastvane na malkiya uchenik [Spiritual-moral growing up of pupil]. Farago.

Vassileva, E.L. (1999). Religioznoto vazpitanie na detsata ot preduchilishtna vazrast: Rakovodstvo za uchitelya [Religious education of preschool aged children: Teacher's manual]. Svyat 2001.

Veleva, Ts. (2016). Balgarskata narodna religiozna pesen v uchebnite pomagala po muzika [Bulgarian folk religious song in musical educational materials]. In I.N. Nikolova, M. Zagarova, \& E. Kovacheva (Eds.), Misal, slovo, text: Vol. 2. Traditsia VS theologiya: Sinergiya i praktika [Tradition vs. theology: Synergy and practice] (pp. 134-147). University press.

Yanev, I.G. (2016). Grizhi za detsa i mladi hora s narusheno zdravoslovno sastoyanie v Sveshtenoto Pisanie: Sluchai na svrahestestveno iztselenie i vazkresyavane [Care of children and youth of compromised health condition in Sacred Scripture: Cases of supernatural healing and being resurrected]. In I.Zh. Dimitrov, S. Kancheva \& I. Naydenov (Eds.), Bibleiska biblioteka: Vol. 11. Dva stalba na hrama (pp. 191-203). Bibleyski collegium.

Yanev, I.G. (2013). Pastirski grizhi za mladite hora v risk [Pastoral care for youth in risk]: Doctoral thesis supervised by B.B. Andonov. Faculty of Theology of Sofia University.

Yanev, I.G. (2012). Prof. prot. D-r Hristo Dimitrov i negoviyat prinos za razvitie na Pastirskoto bogoslovie v Balgariya [Professor protopresbyter PhD Christo Dimitrov and his contribution for the development of Pastoral theology in Bulgaria]. In K.K. Nushev, \& D. Nikolchev (Eds.), Traditsii, problemi, perspectivi [Traditions, problems, perspectives] (pp. 85-92). University Press.

Yanev, I.G. (2011). Pastirski grizhi za detsa i mladi hora v risk v Drevnata tsarkva [Pastoral care for children and youth in risk in Ancient Church]. Bogoslovska misal, 1-2, 41-53.

Yanev, I.G. (2010). Grizhata na enoriyskiya sveshtenik za detsata v risk: Obshti nasoki [Care of parish priest about children in risk: General directions]. In P. Petkov (Ed.), Balgariya i balgarite v Evropa [Bulgaria and Bulgarians in Europe] (pp. 211-216). Faber 


\section{Appendix}

Figure 1. Children have their traditional, new, educational, and ritual place and role in church

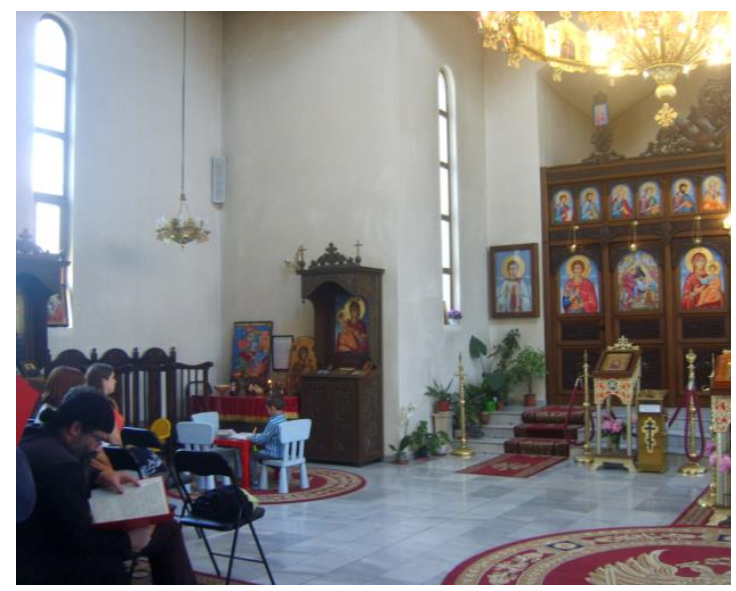

(a)

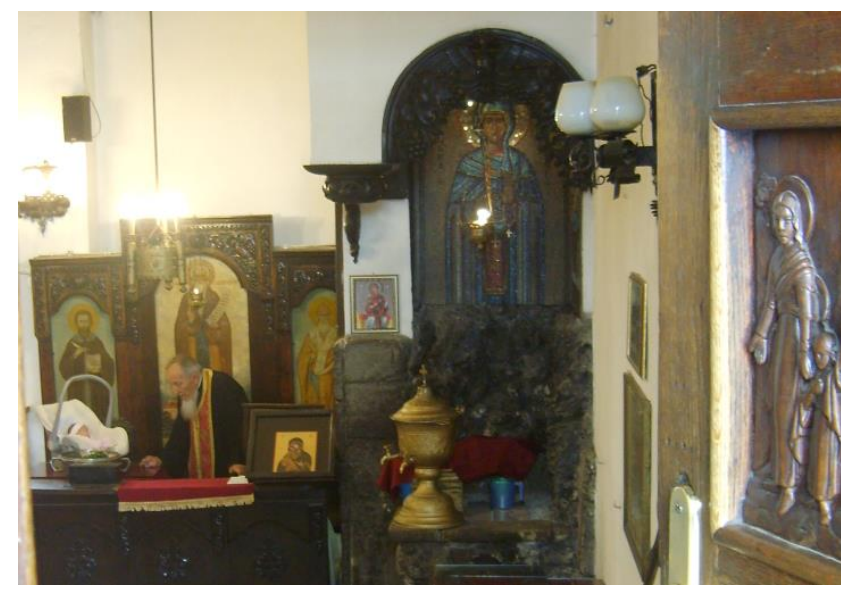

(b)

Note: (a) Space for kids in the nave of Nativity of Christ church in Mladost district of Sofia, where younger parish members are usually accommodated, awaiting their turn to join church services.; (b) Priest welcoming a new born baby girl brought to church for her first blessing.

Figure 2. The long sociocultural way, from inviting a priest to bless water (vodosvet) to demonstration promoting confessional education:

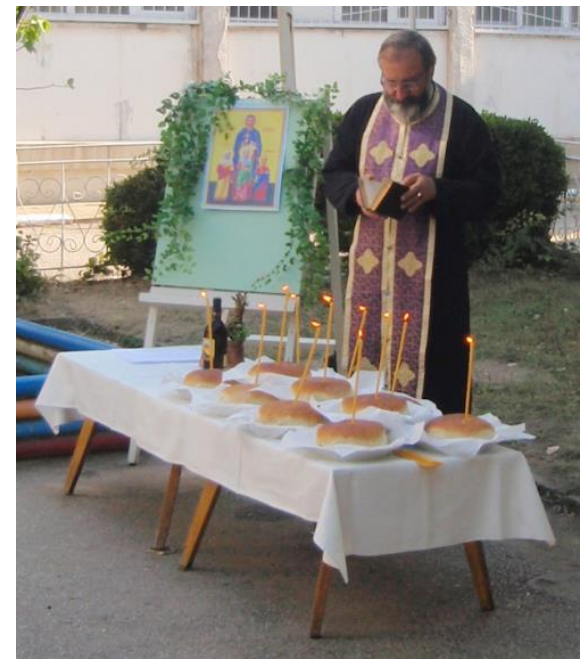

(a)

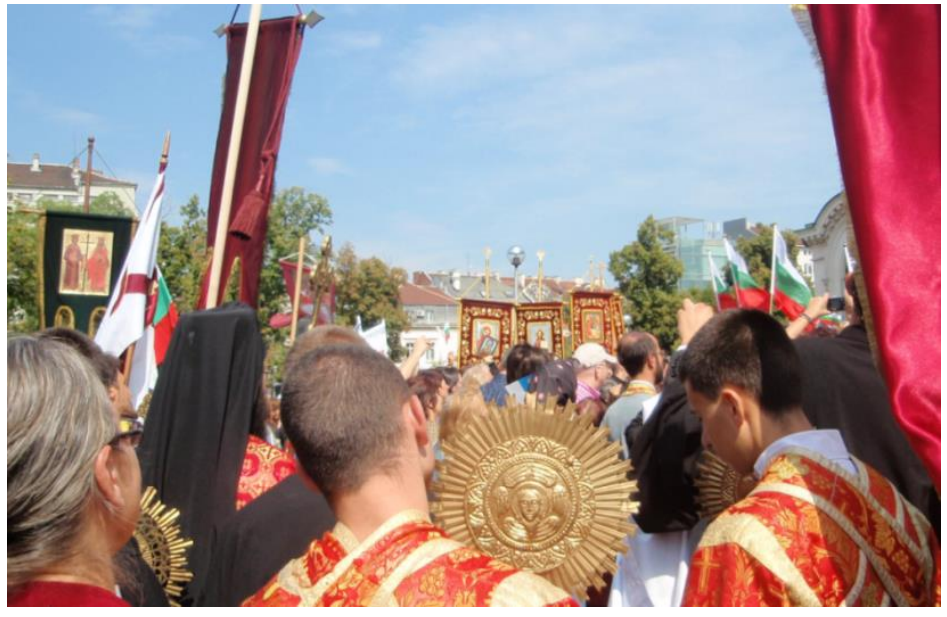

(b)

Note: (a) Parish priest at yearly volunteer blessing of children at public kindergarten on its patron-saints feast and Day of Sofia; (b) Public event at the Saint Alexander Nevsky patriarchal cathedral square in the centre of Sofia, pushing for regular school and kindergarten religious education curriculum (procession - shestvie and concert) with representatives of Bulgarian seminaries, parishes and monasteries, from around the country (Autumn 2010). 
Figure 3. His Beatitude Bulgarian ex-Arch Stephen (Shokov) (Metropolitan of Sofia) at a kid's summer camp (detsko letovishte) in the early 1930s (Photo of church officer Rashko Galabov).

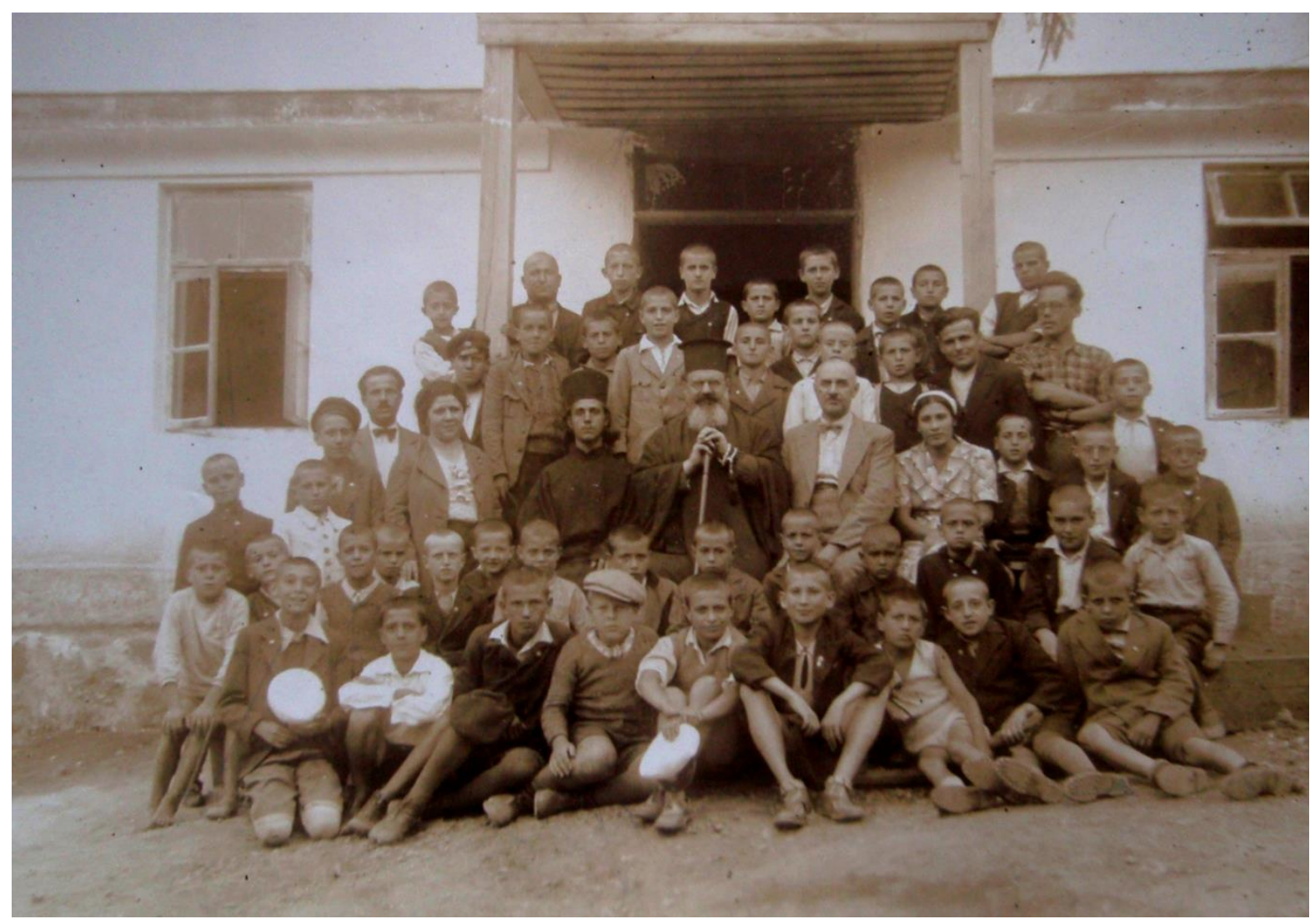


Figure 4. Bulgarian girls at church, kid's summer camp (detsko letovishte) organised by a parish priest in a monastery in the late 1930s (Private archival photograph by Rashko Galabov).

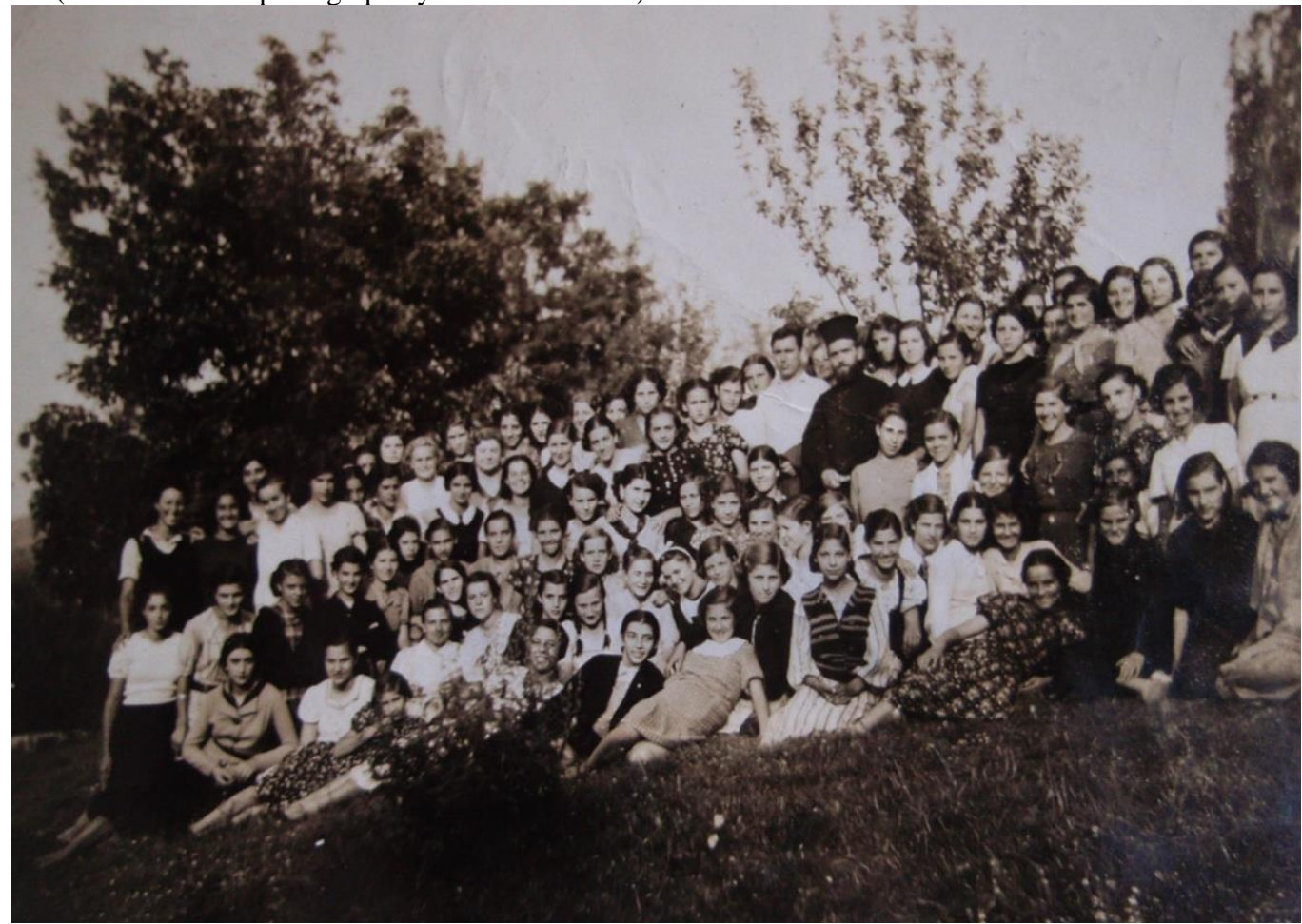


Figure 5. The participation of children in liturgy as vocational training though socially inconceivable as initial religious education, became a real, though limited practice following cultural changes

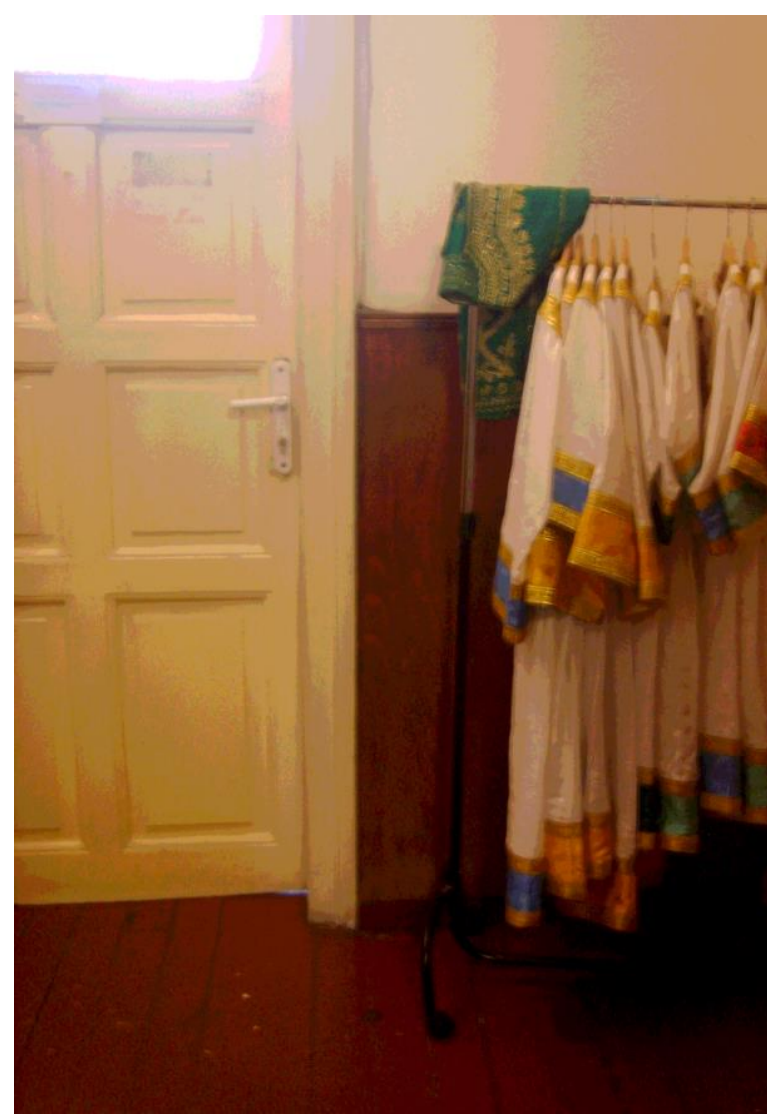

(a)

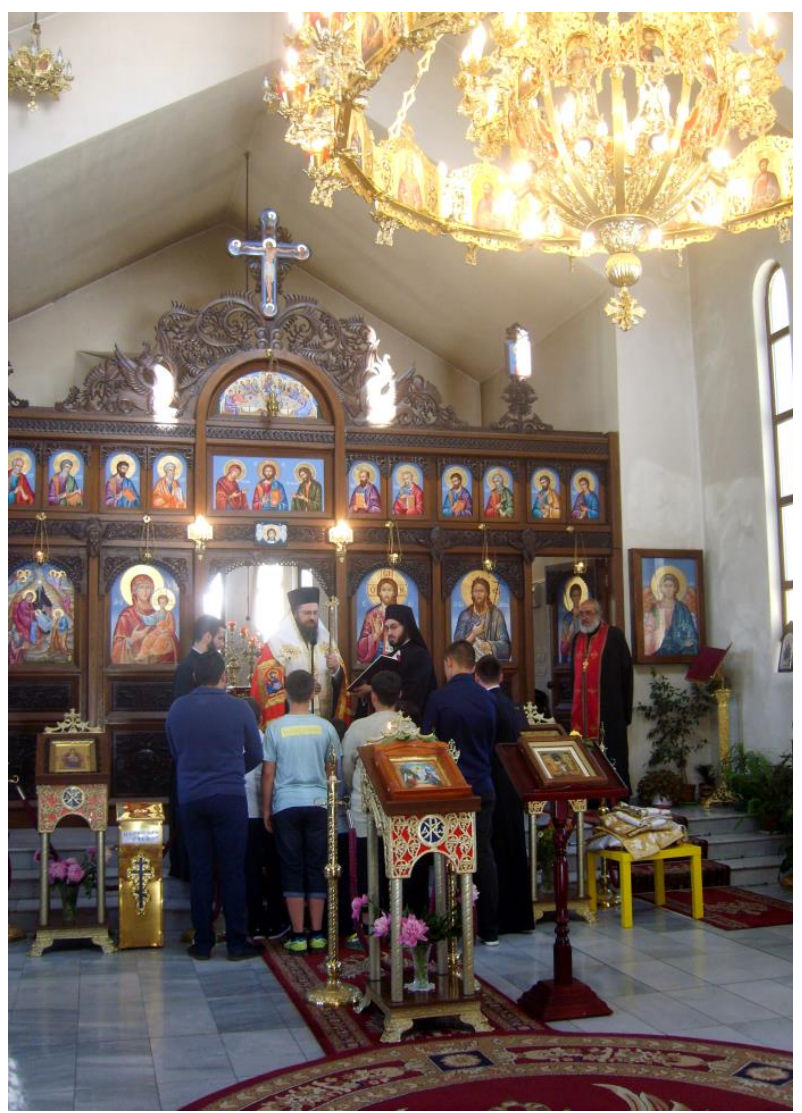

(b)

Note: (a) The room of academic staff teaching homiletics and catechetics: stand with liturgical robes of children participating in services, litanies and youth activities of the parish in Saint Clement of Ochrid academic chapel of the Theological faculty of the Sofia University. (Photo posterised by PhotoFiltre free software); (b) Blessing of youth as church assistants at Mladost's 3rd district parish by His Grace Bishop Polykarp (Petrov), vicar of His Holiness Bulgarian, patriarch and metropolitan of Sofia Neophite (Dimitrov), who organised numerous children and youth events.

(C) 2020 by the authors. Submitted for possible open access publication under the terms and conditions of the Creative Commons Attribution (CC BY) license (http://creativecommons.org/licenses/by/4.0/). 